\title{
Ghuwai Cetik
}

\author{
Aris Tiano ${ }^{1}$ \\ Institut Seni Indonesia Yogyakarta
}

\begin{abstract}
Cetik is a traditional tool Lampung derived from Skala kingdom BrakLampung West. Estimated to have existed since centuries $485 \mathrm{sm}$. While the word comes from Lampung ghuwai which means create, make, do a job. Two words into ghuwai cetik, the musical instrument made of bamboo. Stylist interest by making cetik instrument is the source of the sound produced.

Ghuwai cetik or how to make traditional musical instruments Lampung is an inspiration to stylists to be a theme in the musical composition. After finding inspiration in realizing further various stages such as stages of selection, cutting, tunings and finishing. The method used in the work of this musical composition using the Re-Interpretation and contemporary approach.

Keywords: Ghuwai cetik, Process.
\end{abstract}

\begin{abstract}
Abstrak
Cetik merupakan alat tradisional Lampung yang berasal dari kerajaan Skala BrakLampung Barat. Diperkirakan sudah ada sejak abad 485sm. Sementara kata ghuwai berasal dari bahasa Lampung yang artinya buat, membuat, melakukan suatu pekerjaan. Dua kata tersebut menjadi ghuwai cetik, yakni instrumen musik yang terbuat dari bambu. Ketertarikan penata dengan cara membuat instrumen cetik adalah sumber bunyi yang dihasilkan.

Ghuwai cetik atau cara membuat instrumen musik tradisional khas Lampung ini memberi inspirasi kepada penata untuk dijadikan tema dalam komposisi musik. Setelah menemukan inspirasi selanjutnya berbagai tahapan dalam mewujudkan seperti tahapan pemilihan, pemotongan, pelarasan serta perapihan. Metode yang digunakan dalam karya komposisi musik ini menggunakan Re-Interpretasi dan pendekatan kontemporer.
\end{abstract}

Kata Kunci : Ghuwai Cetik, Proses Pembuatan.

\footnotetext{
${ }^{1}$ Mahasiswa Jurusan Etnomusikologi FSP ISI Yogyakarta.
} 


\section{Pendahuluan}

Kota terbesar di provinsi paling selatan pulau Sumatera yaitu kota Bandar Lampung. Kota Bandar Lampung merupakan ibu kota provinsi Lampung. Secara geografis, kota ini menjadi pintu gerbang utama pulau Sumatera dan memiliki andil penting dalam jalur transportasi darat serta aktifitas perindustrian logistik dari Jawa mau pun sebaliknya. Provinsi Lampung banyak memiliki keanekaragaman seni dan budaya, dengan mengikuti perkembangan zaman, saat ini provinsi Lampung menjadi wilayah yang cukup maju. Bidang kesenian tradisi misalnya, tari, musik, teater dan lain sebagainya tentang seni. Berbicara tentang tradisi lampung, ada satu Kabupaten di provinsi Lampung yang dimana daerah tersebut sangat kental tentang tradisinya. Masyarakat yang memiliki rasa saling menghargai dan menjaga kelestarian budayanya membuat salah satu daerah ini menjadi daerah yang khas. Daerah ini bernama Liwa, tepatnya berada di Lampung bagian barat.

Liwa merupakan ibu kota kabupaten Lampung Barat yang banyak masyarakat menyebutnya kota hujan karena terletak di pegunungan Bukit Barisan Selatan, dan daerah ini terkesan tidak pernah adanya terbit matahari, yang ada hanya embun dengan langit yang sayup seperti musim hujan. Wilayah kota Liwa meliputi seluruh wilayah Kecamatan Balik Bukit. Liwa terletak di jalan simpang yang menghubungkan tiga provinsi, yaitu Lampung, Bengkulu, dan Sumatera Selatan. Daerah ini hanya memiliki satu marga (keturunan/ras) dan satu kecamatan juga terdiri dari 12 pekon (desa/kelurahan). Liwa menjadi khas karena letaknya yang berbeda dengan kota-kota yang ada yaitu daerah pegunungan, dan tentunya banyak pohon-pohon rindang tumbuh dan berkembang di wilayah ini. Liwa merupakan daerah yang subur, sehingga beberapa tanaman seperti Kopi, lada, cengkeh dan lain sebagainya tumbuh subur ditempat tersebut. Liwa juga merupakan daerah bertumbuh kembangnya bambu. Ada yang menyebutkan Liwa daerah istimewa, karena hanya di tempat ini keberadaan bambu tumbuh dengan kualitas yang bagus, berbeda dengan bambu-bambu di daerah lain.

Daerah Liwa hanya terdapat satu jenis bambu yang memiliki ukuran besar dari daerah lain, yaitu bambu betung. Bambu betung mempunyai rumpun yang 
agak sedikit rapat, warna batang hijau kekuning-kuningan, dan ukuran bambu ini lebih besar dan lebih tinggi dari jenis bambu yang lain. Tinggi batang bambu mencapai 20 meter, dengan diameter batang mencapai $20 \mathrm{~cm}$, ruas bambu betung cukup panjang dan tebal pajangnya antara $40-60 \mathrm{~cm}$, serta memiliki ketebalan dinding $1-1,5 \mathrm{~cm}$. Jenis bambu betung bisa dianggap hanya terdapat di Lampung Barat, karena di daerah tersebut merupakan daerah yang memiliki dataran tinggi. Bambu betung sifatnya keras dan bagus untuk dijadikan bahan membuat alat musik. Misalnya seperti instrumen cetik, dengan kriteria bambu yang memiliki serat besar-besar serta ruas yang panjang, maka bambu ini cocok untuk membuat instrumen cetik.

Proses pembuatan instrumen cetik telah penulis alami sendiri. Adapun proses pembuatan instrumen cetik tersebut yaitu, pertama adalah pemilahan bahan bambu. Bambu yang dipilih adalah bambu yang berusia 6 tahun atau yang sudah tua, dengan alasan pencapaian kualitas bunyi yang dihasilkan lebih matang dan bagus. Kedua, masuk ke tahap pemotongan. Bambu tersebut dipotong menjadi lima bagian, kemudian dibuat menjadi sejumlah bilah yang disesuaikan dengan kebutuhan nada. Ketiga, adalah pelarasan nada, hal ini dilakukan dengan cara disayat dengan menggunakan pisau hingga sesuai kebutuhan nada yang akan dicapai. Keempat, kemudian bambu yang sudah disayat dan dilaras tersebut disusun diatas bambu yang sudah dilubangi tengahnya dengan tujuan untuk menghasilkan suara sesuai dengan resonansi yang sudah diatur pada saat bilah dipukul. Tahap pelarasan merupakan bagian yang sangat membutuhkan ketelitian serta kepekaan sebuah pendengaran agar menghasilkan nada yang tepat. Kelima, setelah pelarasan kemudian lanjut memasuki tahap pemasangan. Pemasangan disini maksudnya adalah bahan bilah yang sudah di laras disatukan dengan tali serta pengganjal dan diikatkan dengan tabung cetik sebagai tempat untuk menampung resonansi suara yang dihasilkan oleh bilah bambu tersebut. Fungsi pengganjal adalah sebagai penahan dari tali yang disambungkan, agar bilah tersebut tergantung di atas tali. Setelah melalui proses pemasangan tahap keenam kemudian masuk tahap perapihan agar cetik tersebut terlihat menarik dan rapih 
atau biasa disebut finishing. Proses dan tahapan dalam pembuatan cetik inilah sebagai pengalaman empiris untuk dijadikan dalam komposisi musik.

\section{Pembentukan}

Karya musik yang berjudul Ghuwai Cetik berangkat dari proses pembuatan cetik terdiri dari 4 (empat) bagian. Bagian pertama disajikan dengan suasana pemilahan bambu. Dimulai dengan video pemotongan bambu secara streming serta dilanjutkan dengan vokal seruan lampung yang menandakan hasil proses pemilhan bambu sudah selesai. Dilanjutkan dengan pemain satu-satu persatu sambil nyambay (lagu tradisi Lampung yang berisi tentang ajakan serata rayuan).alat yang digunakan adalah gong cundang (gong tradisi lampung terbuat dari pipa paralon).

Pada bagian kedua disajikan dengan suasana saat pemotangan bambu menjadi bilah. Dimulai dengan peniupan bambu betung yang sudah dilubangi berbentuk suling, tetapi ukuranya lebih besar. Kemudian yang lain mengikuti. Setelah itu mengambil golok untuk melakukan pemotongan dengan menggunakan ritmis tradisi Lampung yang sudah dikembangkan.

Pada bagian ketiga disajikan ketika suasana pelarasan nada pada bambu yang sudah menjadi bilah. Satu pemain meembuat pola ritmis dan pemain lain mengikuti dengan menggunakan ritmis tradisi Lampung yang sudah dikembangkan langsung mulai pegesakan pada bilah bambu sesuai nada yang diinginkan.

Pada bagian keempat menggambarkan suasana perapihan. Dimulai dengan permainan pola gong cundang menggunakan tempo cepat bersama diiringi oleh vokal muayak Lampung. vokal ini disajikan agar suasan tradisi Lampung lebih melekat. Sesudah itu dimulai dengan permainan cetik dengan menggunakan tehnik unison dan canon agar suasana pembuatan cetik lebih bisa dirasakan.

\section{Ulasan Karya}

Bagaimanapun juga seni berasal atau berpijak dari situasi konkrit manusia, sehingga konteks selalu mewarnainya. Dalam pencetusan sebuah gagasan yang 
muncul inilah, penata mencoba mengangkat sebuah ide penciptaan yang lahir ketika penata merenung dan mengingat kembali tentang kejadian proses yang dilalui salah satunya yaitu membuat instrumen cetik. Pada kejadian itu penata baru belajar membuat instrumen tersebut. Sangatlah susah sekali pada awal nya dimana penata harus bisa memilih bambu, membelah bambu dan dibentuk sesuai ukuran serta melaraskan dengan nada cetik tersebut. Penata menyadari betapa susah nya membuat instrumen tersebut. Dari pengalaman tersebut penata mengambil konsep pembuatan cetik dimana suasana tersebut sangat berharga bagi penata yang tadinya tidak bisa membuat jadi tahu cara membuatnya. Selanjutnya sejauh mana sumber itu akan diolah dan diciptakan kembali sangat tergantung pada intensi, mood, olahan perasaan dan gagasan yang dituangkan dalam komposisi. Hasilnya bisa jadi mirip sekali, seirama, senada dan bahkan bisa berlawanan atau bertolak belakang. Apabila penciptaan yang baru ini sangat berbeda dengan sumber penciptaannya, sehingga tidak tampak (secara transparan) sama sekali dengan sumbernya, maka tataran sumber yang diacu hanya sebagai ilham saja. Bagaimana pun juga ada perbedaan antara ilham dan sumber penciptaan.

\section{Tema}

Sebuah karya musik, alangkah baiknya menentukan tema terlebih dahulu agar musik yang akan dibuat lebih tersusun seperti yang diinginkan komposer itu sendiri. Tema adalah pokok pikiran, dasar cerita yang dipercakapkan dipakai sebagai dasar mengarang, menggubah sajak, dan sebagainya (Moeliono, 1999: 1029). Cara mencari tema dapat dilakukan dengan berbagai macam cara antara lain dengan melakukan eksplorasi (penjelajahan). Eksplorasi dapat diartikan penjajakan: penjelajahan untuk mencari sesuatu keberadaannya yang belum diketahui; penyelidikan: kegiatan studi untuk memperoleh pengalamanpengalaman baru disituasi yang baru (Marianto, 2006: 11). Eksplorasi yang dilakukan biasanya eksplorasi yang bersumber dari alam, pengalaman hidup, peristiwa sehari-hari, rekaman audio, rekaman visual atau rekaman audio visual dan sebagainya. 
Tema dengan judul diupayakan sesuai dengan alur cerita yang telah disusun dalam stuktur penyajiannya untuk mempermudah imajinasi penonton menangkap pesan-pesan dari karya tersebut. Harapan seorang komposer yaitu pesan-pesan dari karya tersebut dapat mempengaruhi pemikiran penikmatnya. Tema dari garapan ini ialah proses pembuatan cetik. Proses pembuatan cetik ini merupakan pengalaman empiris penata ketika belajar membuat cetik.

\section{Bentuk (Form)}

Secara penyajiannya karya ini mengacu pada konsep tradisi lampung. dimana konsep tersebut terdiri dari Tabuh Gupek (riuh), Tabuh Tari (lambat) dan Tabuh Gupek. Komposisi ini merupakan kemasan karya musik tradisi baru dalam suasana pembuatan cetik yang disajikan secara pagelaran. Alunan vokal tradisi lampung seperti Muayak dan nyambai ikut andil dalam komposisi ini, agar suasana tradisi Lampung masih terasa. Komposisi ini dibagi menjadi 5 bagian yaitu introduksi, bagian 1 , bagian 2 , bagian 3 dan bagian 4 . Dalam penyajiannya didukung oleh gerak pemain (penabuh) yang ditata sedemikian rupa. Bentuk ritmis serta suasanya yang telah dicapai sedapat mungkin dipertimbangkan secara seksama dengan kaedah-kaedah penggarapan komposisi musik. Penataan susunan musik sedikit demi sedikit ditata ulang dan dibersihkan tekniknya agar jelas instrumen mana yang mendapat penonjolan, keras lirih, speed (kecepatan), dan durasi waktu yang diperlukan. Dalam garapan ghuwai cetik ini penata mendapat inspirasi dari pembuatan cetik. Dimana terdapat beberapa proses yang harus dilakukan untuk membuat instrumen tersebut yaitu proses pemilahan bambu, pemotongan atau pembentukan, pelarasan serta perapihan. dari inspirasi tersebut penata mengangkat pola tawa-tawa lampung yang didalamnya terdapat suasana yang dibutuhkan dalam garapan ini yaitu pemilihan dan ketenangan. Pola tawatawa tersebut tidak diambil secara mentah, melainkan dikembangkan sesuai dengan kaidah-kaidah atau elemen-elemen musik pada umumnya. Adapun pola tawa-tawa tersebut adalah sebagai berikut.

- $9 \cdot j D D j \cdot D$ D j.D j.D j.D

Pola ritmis tawa-tawa di atas diolah dan dikembangkan dengan menggunakan 
metode pengolahan motif dalam musik barat seperti, ellis (pengurangan), retrograsi (perombakan), dan pelebaran Sehingga menjadi seperti berikut.

Pola tawa-tawa ini terdapat dibagian introduksi. Adapun pola lain dari tradisi lampung antara lain pola tabuh khapot, tabuh jakhang tidak semata-mata mentah masing pola ada perkembangan nya. Laras yang digunakan dalam garapan ghuwai cetik yaitu laras pelog serta bunyi-bunyian dari suara tempahan golok kebatang bambu.

\section{Strukstur Musikal}

Struktur garapan ini telah dipertimbangkan alur dari bentuk musik yang digarap. Keseimbangan antara bagian ke bagian berikutnya terstruktur menjadi satu kesatuan yang saling terkait. Dilihat dari strukturnya, komposisi ghuwai cetik terdiri dari 5 bagian yaitu: Intro, Bagian I, Bagian II, Bagian III dan Bagian IV.

Pada bagian introduksi, akan diputar video proses pemilihan bambu sebagai perantara agar nuansa yang dihadirkan masih berkesinambungan. selanjutnya salah satu pemain memberikan isyarat menggunakan seruan sapaan bahasa lampung yaitu tabuh pun yang artinya ajakan untuk memulai tabuhan, dan dijawab oleh pemain lainya secara serentak dengan kalimat ya pun yang artinya mari kita menabuh.

Vokal isyarat Lampung :

$$
\begin{aligned}
& \text { | } \begin{array}{llllllll|lll}
5 & j .4 & j 34 & 5 & j 75 & j 43 & j 45 & 3 & j 55 & 5
\end{array} \\
& \text { e.e ie e oo oo o o tabuh pun }
\end{aligned}
$$

dijawab unison: ya pun

artinya : mari menabuh dijawab ya mari

Keterangan : Vokal ini dimainkan dengan tempo bebas dan nada tidak ditentukan, berbentuk teriakan atau aba-aba.

\section{Bagian 1}

Pada bagian 1 ini penata membaginya menjadi tiga bagian. Dibagian awal ini pemain masuk ke dalam panggung dengan cara satu persatu melalui sisi kanan dan sisi kiri penonton alasan penulis membuat seperti demikian adalah ingin menghadirkan tehnik muncul yang berbeda pada umumnya. pemain pertama 
masuk dengan motif tawa-tawa yang sudah dikembangkan sebagai berikut:

Pola tawa-tawa tradisi lampung

$$
{ }_{-} \text {jDD j.D D j.D j.D j.D h }
$$

Dikembangkan dengan menggunakan tehnik ellis ( pengurangan ) dan retrogasi ( perombakan ) sehingga menjadi :

$$
\text { _ D J.D D D | D j.D D D _ }
$$

Keterangan : D : dibaca dung.

Kemudian semua pemain masuk dengan syair. Adapun syair yang digunakan adalah syair nyambai ( irama vokal tradisi lampung ) berikut nyambai yang digunakan :

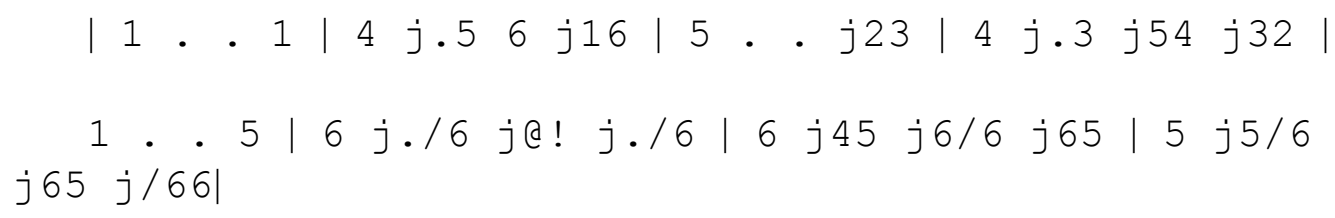

Keterangan $: j j 1 j 2 j 3 .=$ dibaca dengan tangga nada diatonis

Syair ini merupakan wujud motivasi keceriaan sehabis pulang dari hutan. Setelah itu masuk vokal muayak Lampung (muayak merupakan vokal tradisi Lampung yang berisikan tentang nasehat) dengan irama bebas.

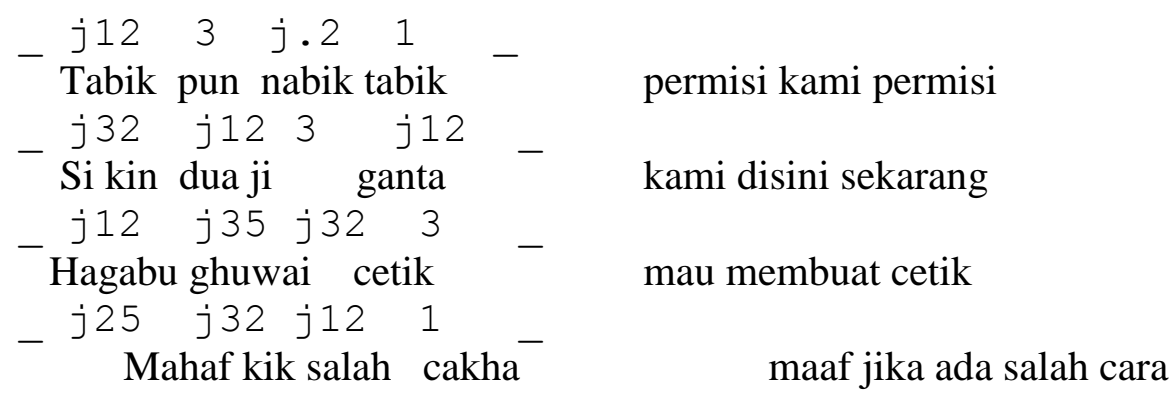

Kemudian para pemain menuju kebelakang stage untuk melakukan persiapan kegiatan pemotonga bilah bambu. Persiapan ini disajikan dengan suasana permain pipa paralon sebagai imitasi dari bambu. Adapun pola ritmis yang dimainkan adalah pola ritmis tradisi lampung yaitu tawa-tawa yang sudah dikembangkan dengan memakai metode musik barat yaitu, elise, sekwen, interloking, dan retrogasi. 
Pola tradisi tawa-tawa :

$$
\text { - } g \cdot j D D j \cdot D \text { D j.D j.D j.D }
$$

Pola tradisi yang sudah dikembangkan :

$$
\begin{aligned}
& { }_{-1} \cdot 2 \cdot \mid 5 \cdot j 671 \text { _ } \\
& \text { Irama A : j11 j55 j11 j22 _ }
\end{aligned}
$$

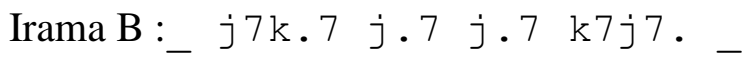

Keterangan : j11 j55 = dibaca dengan tangga nada diatonis

Alasan penulis menggunakan motif ini adalah sebagai perwujudan dari kesibukan ketika para pekerjaan melakukan suatu kegiatan.

\section{Bagian 2}

Pada bagian ini di bagi menjadi tiga bagian. Pada bagian awal dibagian ini mula satu pemain masuk dengan menggunakan instrumen tiup yaitu Serdam (alat tradisional Lampung berbentuk suling yang mempunyai 3 lobang dan 4 nada yaitu 1(do), 2(re), 3(mi) dan 5(sol)). Pola serdam ini dimainkan secara improvisasi tetapi tetap berpijak pada unsur tradisi lampung. agar pemain tidak salah ketika melakukan improvisasi, dilanjutkan dengan pemain lainnya menggunakan tehnik yang sama. Tetapi media yang digunakan adalah bambu yang sudah dipotong menjadi satu ruas. Mula-mula dimainkan satu pemain sebagai pembuat tempo dengan pola sebagi berikut :

$$
\text { | D D jDI jII | }
$$

Keterangan: pola diatas merupakan pola improvisasi sebagai tempo. $\mathrm{D}=$ dung $\quad \mathrm{I}=$ tak.

Bagian dua dari bagian ini merupakan wujud eksplorasi dari bambu yang dilakukan dengan cara ditiup. Adapun alasan penulis melakukan ini adalah sebagai perwujudan suara hembusan angin yang di imitasi kedalam bentuk komposisi musik dengan menggunakan perkembangan tradisi. Memakai tehnik elise, augmentasi, repetisi dan retrogasi tetapi tetap berpijak pada unsur tradisi Lampung.

Adapun pola ritmisnya adalah sebagai berikut : 
jhh j.h.h j.h h.|j.h h h j.h h j.h h |j.h j.h j.h h $j \cdot h h \mathrm{~h} \mid j h h j \cdot h \mathrm{~h} j . h j \cdot h j \cdot h \mathrm{~h}$

Keterangan : Notasi di atas dimainkan dengan cara ditiup pada bagian bambu yang sudah dilubangi.

Pada bagian tiga dari bagian ini merupakan perwujadan suasana pemotongan bambu menjadi bilah cetik. Suasana ini dimainkan dengan menggunakan pola salsa (salasa merupakan irama amerika latin diterapkan dalam pola perkusi). Adapun alsan penulis menggunakan irama ini. Merupakan perwujudan dari kegiatan pemotongan bambu. Dimana pemotongan bambu sendiri tidak tertata. Penulis hanya mengambil sedikit bagian dari kegiatan itu yaitu unsur bunyi yang dikemas menjadi suatu komposisi. Irama ini dipadukan dengan tehnik interloking agar nuansa yang dihadirkan terkesan ramai dan gembira. alat yang digunakan sebagai media ungkap yaitu golok (suatu alat pemotong kayu) dan bambu Adapun iramanya adalah sebagai berikut :

| kDjDI jDI kDjDI jDI kDkIkD. kIkIkI. kDkIkD. kIkIkI. | $j K K \quad j K K \quad j K K \quad j K K \quad \mid$

Pola a: _ kDkIk.D jID k.jID jII

Polab: _ jID k.kIk.D k.kIk.D jII _

Keterangan : $\mathrm{D}=$ bambu beradu dengan lantai

I = bambu beradu dengan golok

$\mathrm{K}=$ golok bergesekan dengan bambu

\section{Bagian 3}

Pada bagian ini penulis menbaginya menjadi tiga bagian. Bagian pertama dari bagian ini diawali dengan suara hentakan secara unison. Sehabis itu dilanjutkan permainan pola kimbang (tabuhan dasar dari tehnik dasar rebana Lampung) yang dilakukan secara unison. Kemudian ada satu pemain melakukan tehnik permainan improvisasi secara bergantian dan ada dua pemain lainnya menggunakan amplas (alat penghalus kayu berwujud kertas kasar). Alasan penulis menggunakan tehnik ini adalah sebagai perwujudan imitasi dari kegiatan pemotongan bambu menjadi bilah cetik. Adapun pola dasar kimbang yaitu :

- D I j.D I _

Keterangan : $\mathrm{D}=$ Dung pada pola permainan rebana 


$$
\text { I }=\text { Tak pada pola permainan rebana }
$$

Pola di atas tidak semata-mata langsung dimainkan. Tetapi diubah ritmis nya memakai tehnik elise serta contras permaina amplas. Ini dilakukan agar perwujuadan suasana kegiatan lebih didapat dan penonton bisa memahani apa yang diinginkan oleh peulis tentang suasana kegiatan membuat cetik. Adapun pola yang dimainkan adalah sebagai berikut :

Pola a:_ D I D I

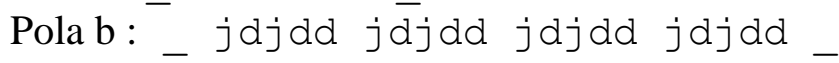

\section{Keterangan :}

$\mathrm{D}=$ Dug pertemuan bambu dengan lantai

I $=$ Tak pergesekan golok dengan bambu

$\mathrm{d}=$ Ritmis amplas bergesekan dengan bambu.

Setelah melakukan kegiatan pemotongan, kemudian masuk ketahap penghalusan bilah cetik yang dilakukan secara canon (tehnik pergantian pemain). Suasana ini diwujudkan dengan permainan tradisi lampung yaitu khapot (pola tabuhan lampung) yang diimitasikan lewat permainan bilah cetik secara canon. Ditehnik permainan ini titik fokus lebih diutamakan. Karena setiap pemain hanya menghafal nada atau tanda yang sudah diberikan. Alasan penulis menggunakan tehnik ini adalah agar setiap pekerjaan yang dilakukan secara sungguh-sungguh dan konsentrasi. Adapun pola yang dimainkan adalah sebagai berikut :

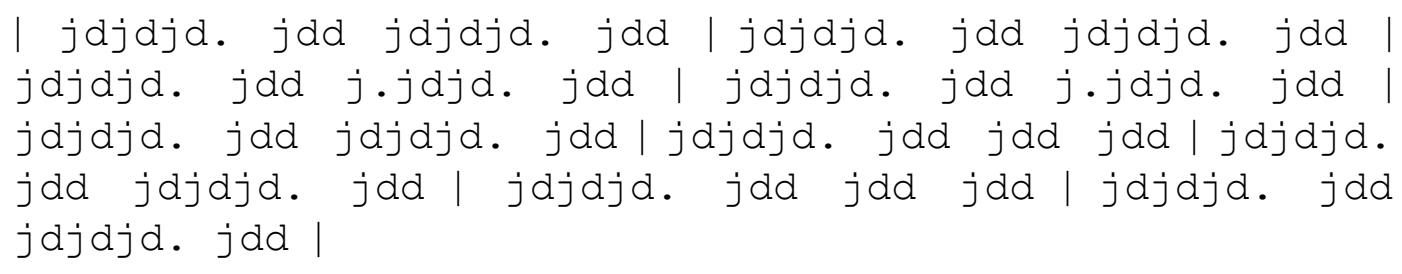

Keterangan : d : ritmis amplas bergesekan dengan bambu.

Pada bagian kedua dihadirkan permainan bilah cetik. Diawali dengan permainan satu orang pemain dan tiga pemain lainya mengikuti. Tehnik permainan nya menggunakan tehnik canon, agar dinamika komposisi musik ini lebih terasa. Sedangkan tiga pemain menggunakan tehnik filler (saling mengisi) memakai pola tradisi yang dikemas dengan tehnik musik barat yaitu elise, 
Diminusi dan retrogasi. Adapun alasan penulis menggunakan pola ini agar perwujudan suasana bilah cetik sudah dihuluskan, akan tetapi bilah tersebut belum disamakan nada nya pada instrumen cetik. Adapun permainan ritmis bilah sudah jadi adalah sebagai berikut :

$$
\begin{aligned}
& \text { Pola a: }{ }_{-} j_{B B} j V j V V \text { jVjVV jVjVV } \\
& \text { Polab: }{ }_{-} B k \cdot V j \cdot V j \cdot V k V j V .
\end{aligned}
$$

\section{Keterangan :}

$\mathrm{B}=$ ketukan berat ritmis pada bilah cetik

$\mathrm{V}=$ ketukan samar-samar pada bilah cetik

Pola $\mathrm{a}=$ dimainkan secara bergantian

Pola $\mathrm{b}=$ dimainkan 3 pemain secara interlocking

Berikut ini pola permain bilah cetik yang belum dilaras :

| j/1j/2j/3. /j2/3/j1/j2/j3. /j2/3|j/j1/j2/j3.j/2/3 /j1/j2/j3. /j2/2 |j1j2j3. j23 j1j2j3. j23|jj1j2j3. j23 $j 1 j 2 j 3 . \quad j 22 \mid$ | /j1/j2/j3. /j5/6 j./j6/j6. /j6/6 | /j1/j2/j3. /j5/6 j./j6/j6. /j6/6|j1j2j3. j56 j.j6j6. j66 | j1j2j3. j56 j.j6j6. j66 | /j5/j6/j7. /j6/7 /j5/j6/j7. /j6/7 | /j5/j6/j7. /j6/7 /j5/j6/j7. /j6/6 | $j 5 j 6 j 7 . j 67$ j5j6j7. j67 | j5j6j7. j67 j5j6j7. j66 | $j / 1 / j j 2 / j 3 . / j 5 / 3 / j 5 / 3 / j 5 / 3 \mid j / j 1 / j 2 / j 3 . / j 5 / 3$ $j / 1 j / 2 / j 2 . \quad / j 1 / 2 \mid j j 1 j 2 j 3 . j 53$ j53 j53 |jj1j2j3. j53 $j 1 j 2 j 2 \cdot j 12$

\section{Keterangan :}

$/ / 1$ = merupakan nada bilah cetik yang belum tuning

$2=$ merupakan nada yang sudah jadi cetik utuh

$j j 1 j 2 j 3 . \quad=$ dibaca dengan tangga nada diatonis

Pada bagian ketiga penulis menghadirkan suasana pelarasan bilah cetik yang belum jadi nada. Agar bilah tersebut nada nya sama dengan cetik. Suana ini diimitasikan oleh tehnik permaina bilah cetik dengan golok. Alasan penulis menggunakan tehnik ini agar suasan pelarasan bilah cetik lebih bisa dibahasakan lewat komposis musik. Adapun pola permainnya adalah sebagai berikut :

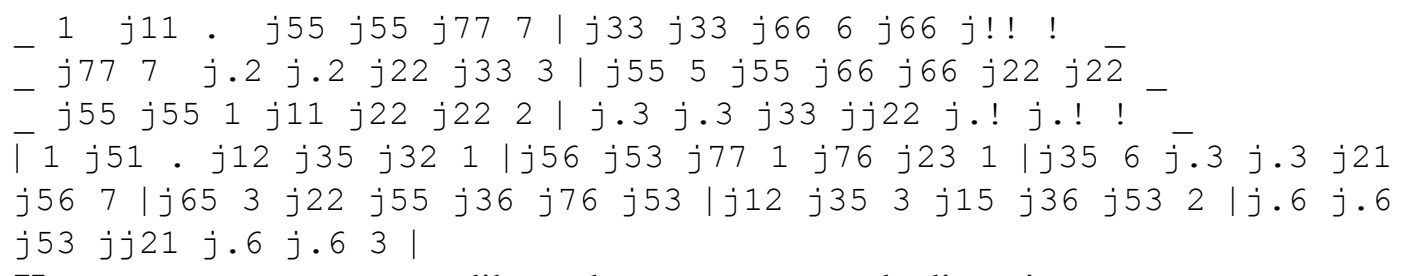

Keterangan : j55 j55 dibaca dengan tangga nada diatonis. 
Pola permainan diatas dimainkan secara bergantian. Setiap pemain fokus dengan satu nada, dan apabila disatukan akan menjadi sebuah alunan melody yang harmonis. Alasan penulis menghadirkan tehnik permainan ini agar pemain bisa merasakan bahwa untuk melaras bilah cetik bukan perkara yang mudah. Dibutuhkan konsentrasi yang kuat agar nada yang diinginkan sama. Setelah itu masuk irama berikutnya sebagai penanda bahwa bilah cetik tersebut nada nya sudah sama dengan cetik. Berikut pola yang dimainkan :

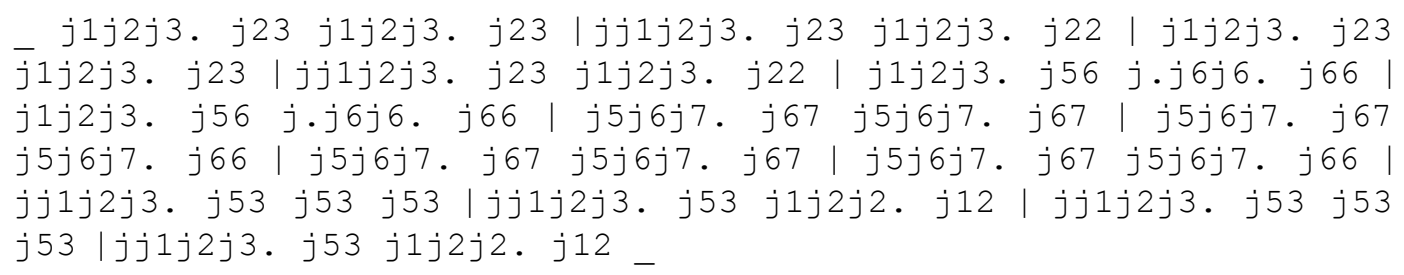

Keterangan : j55 j55 dibaca dengan tangga nada diatonis

\section{Bagian 4}

Pada bagian ini penulis membaginya menjadi tiga. Pada bagian awal penulis menghadirkan suasana telah selesai pelarasan. Ini dihadirkan dengan permainan gong cundang serta muayak. Kesan tradisi penulis hadirkan. Dikarenakan penulis ingin mengangkat tradisi lampung. agar eksistensi tradisi lampung tetap terjaga. Disaat yang sama para pemain lainya melakukan improvisasi terhadap instrumen yang ada disekitar stage. Dengan demikian suasana santai sehabis pekerja tetap terjaga. Bagian ini awal nya dimainkan gong cundang berikut pola permainannya: 1 .j.2 $5|1 \cdot j .2 j 52| 6 \cdot j .5 j 75 \mid 6 \cdot j .5 j 75$

Pola di atas merupakan hasil perkembangan pola tabuh khapot. Yang dikemas dengan menggunakan tehnik elise, augmentasi, sekwen dan retrogasi. Sehingga menjadi satu kesatuan melody yang harmonis. Berikut ini ada syair muayak tradisi lampung :

Vokal muayak: Ajo ya ghuwaian sa

Gamol betung suasa

Jama kham sai wat dija

Mahaf ki salah cakha

Artinya : Ini dia kerjaan

Memukul bambu kuning 


\section{Kepada kita yang disini}

Maaf jika ada salah cara

Pada bagian kedua penulis menghadirkan dari kebebasan instrumen cetik. Dibagian ini penulis memberikan sebuah terobosan baru tentang cetik itu sendiri. Berpijak dari instrumen cetik, penulis memberikan nuasa baru dengan posisi instrumen cetik yang berbeda. Instrumen cetik ini menggunakan system bongkar pasang. Apabila disatukan akan menjadi instrumen cetik, bila dipisah akan menjadi cetik dengan bilah satu. Pada bagian ini posisi cetik bilah dibagi posisi nya. Ada yang dikedua tangan dan ada yang dikedua kaki. Alasan penulis menggunakan terobasan ini adalah ingin menghadirkan tehnik dan nuansa baru dipermainan cetik. Bagian ini diawali dengan permainan gong cundang dengan tempo cepat. Tempo ini menghadirkan suasana riang. Dimana suasana tersebut dilihat dari pola permainan cetik. Kemudian masuk pemain lain yang sudah siap dengan cetik bongkar pasang. Yang dikenakan dikedua kaki dan kedua tangan pemain. berikut pola potongan setiap instrumen :

Gong cundag tangan kiri : _ j1k.5 j.5 j.5 k5j2.

Cetik tangan kanan : _ j1k23 j23 j1k23 j23

pola bambu tangan kiri : _ I I I I

pola cetk tangan kanan : ${ }_{-}$j1k35 6 j5k35 6

Cetik pisah $\quad:$ j23 j52 j35 j65

Cetik pisah: _ j15 j.6 j.7 j67

Pola cetik tangan :

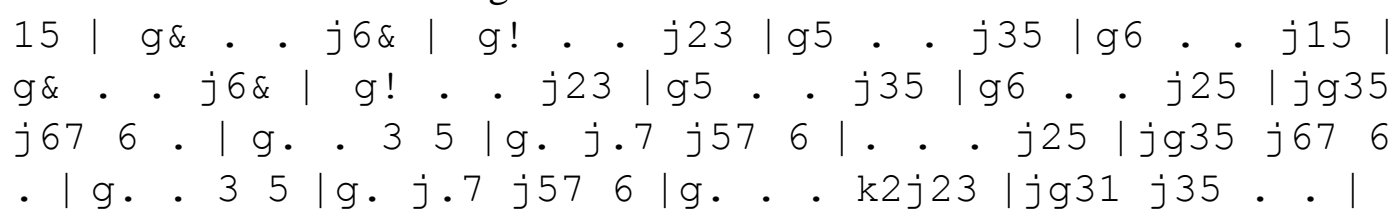

\section{Keterangan :}

* j1k35 = dibaca dengan tangga nada diatonis

* I I = bunyi bambu yang dibenturkan ke lantai, sebagai pembawa tempo.

* g = tanda rall agar susten bambu terdengar panjang

Pada bagian ending permainan cetik dengan aktraktif. Adapun perwujudan suasana yang dicapai adalah hasil dari pembuatan cetik. Dimana proses-proses yang dilewati terjawab dibagian ending ini. Adapun alasan penulis menghadirkan 
suasana ini agar penonton sadari bahwa membuat sebuah instrumen perlu proses yang panjang dan tidak mudah. Dari alasan tersebut penulis menggunakan tehnik permainan canon. Dimana para pemain harus tetap pada tempo yang sudah ditetapkan dan diutamakan fokus dalam tehnik ini serta kepekaan nada dan dinamika. Apabila dimainkan secara bersamaan akan menjadi jalinan melody yang harmonis dan dinamis. Pada bagian irama yang dihadirkan penulis yaitu 3/4. Irama ini dimaksud sebagai perwujan kegembiraan bahwa hasil pembuatan instrumen cetik tersebut sudah selesai. Suasana ini diawali dengan permainan dua pemain secara unison dan dilanjutkan dengan lima pemain lainya. Berikut pola yang dimainkan dibagian terakhir :

Pola solo:

j12 j35 5 | j12 j35 5 | j12 j35 j57 | j.7 j.7 j65|j65 j33 j53

Unison dan canon:

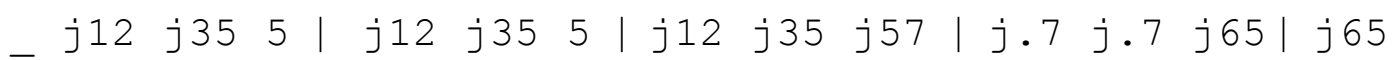
j33 j53 | j21 j6! j75 |j35 j35 2 | j12 j35 5 _

\section{Keterangan :}

j12 j35 5 = dibaca dengan tangga nada diatonis

\section{Penutup}

Komposisi ghuwai cetik merupakan salah satu komposisi eksplorasi bunyi yang mencoba menuangkan inspirasi dalam bentuk bahasa musikal dengan media ungkap cetik lampung, amplas kertas, golok, serdam, bilah cetik, bambu dan gong cundang sebagai sumber bunyi. Teknik permainan alat yang digunakan merupakan teknik perkusi dan etnis-etnis lainnya yang penata dapatkan selama menimba ilmu di Jurusan Etnomusikologi, FSP, ISI, Yogyakarta dengan memanfaatkan integrasi hitungan ritmis yang variatif.

Komposisi ini disajikan dalam bentuk musik murni (pagelaran) yang disajikan secara atraktif karena penata ingin mendapatkan warna tersendiri 
dalam pementasan. Gerak laku pemain ditata dan para pemain tidak terpaku pada satu instrumen saja, dengan harapan konsep dari ghuwai cetik bisa dirasakan secara seksama baik dari pemain maupun penonton.

\section{Daftar Pustaka}

Bahari, Nooryan. 2008. Kritik Seni. Yogyakarta : Pustaka Pelajar.

Djelantik, A.M. 1999. Estetika Sebuah Pengantar. Bandung: Masyarakat Seni Pertunjukan Indonesia.

Djohan. 2009. Psikologi Musik. Yogyakarta: Best Publisher.

Harjana, Suka. 2004. Musik Antara Kritik dan Apresiasi. Jakarta: Kompas.

Hawkins. Alma M. 1990. Mencipta Lewat Tari. Yogyakarta: ISI Yogyakarta.

Mack, Dieter. 2004. Musik Kontemporer dan Persoalan Intelektual. Yogyakarta: Arti.

Marianto, M. Dwi. 2006. "Metodologi Penciptaan Seni” dalam Surya Seni: Jurnal Penciptaan dan Pengkajian Seni Volume 2 No 1.

Moeliono, Anton M. 1999. Kamus Besar Bahasa Indonesia. Jakarta: Balai Pustaka.

Prier SJ, Karl Edmund. 1996. Ilmu Bentuk Musik. Yogyakarta: Pusat Musik Liturgi.

Pramono, Katini. 2008. Horizon Estetika. Yogyakarta : Kahfi Offset.

Purwadarminta. 1976. Kamus Umum Bahasa Indonesia. Jakarta: Balai Pustaka.

Sofyan Yacub, L.Lya dan M. Dahlan. Y. Al-Barry. 2003. Kamus Induk Istilah Ilmiah Seri Intelektual. Surabaya: Target Press Surabaya.

Rachmawati, Yeni. 2005. Musik Sebagai Pembentuk Budi Pekerti Sebuah Panduan Untuk Pendidikan. Yogyakarta: Panduan. 
Waridi. 2006. "Memaknai Kekaryaan Karawitan: Dari Sudut Pandang Pendekatan Penciptaannya" dalam Selonding Jurnal Etnomusikologi Indonesia, Vol III nol. Yogyakarta : Masyarakat Etnomusikologi. 